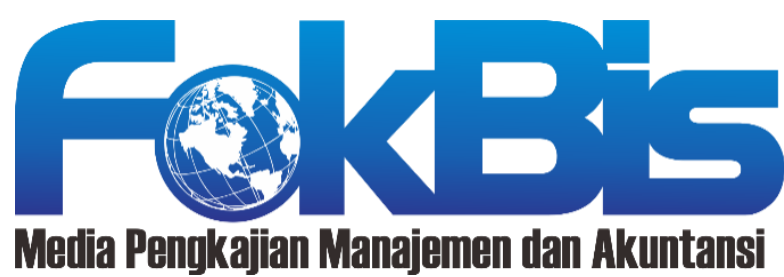

http://journal.stieputrabangsa.ac.id/index.php/fokbis/index

ISSN: 2623-2480/ P-ISSN: 1693-5209

\section{Pengaruh Profitabilitas, Likuiditas, dan Solvabilitas terhadap Nilai Perusahaan dengan Mediasi Harga Saham pada Perusahaan Makanan dan Minuman di Indonesia}

\author{
Ahmad Idris \\ Universitas Islam Kadiri \\ email: ahmadidris@uniska-kediri.ac.id
}

\section{Article Information}

\section{History of Article:}

Received February 2nd 2021

Accepted May $5^{\text {th }} 2021$

Published July $31^{\text {st }} 2021$

\section{DOI:}

10.32639/fokusbisnis.v19i2.742

\begin{abstract}
ABSTRAK
Tujuan penelitian ini untuk mengetahui peran mediasi harga saham dalam pengaruh profitabilitas, likuiditas, dan solvabilitas terhadap nilai perusahaan. Harga saham menggunakan harga penutupan di pasar modal, profitabilitas menggunakan return on asset (ROA), likuditas menggunakan current ratio (CR), solvabilitas menggunakan debt to equity ratio (DER) sedangkan nilai perusahaan menggunakan price to book value (PBV). Populasi dalam penelitian ini adalah perusahaan makanan dan minuman yang terdaftar di Bursa Efek Indonesia (BEI) periode 2014-2019. Sampel penelitian yang digunakan sebanyak 60 data laporan keuangan. Teknik pengambilan sampel menggunakan purposive sampling. Teknik analisis menggunakan analisis jalur. Hasil penelitian didapatkan profitabilitas berpengaruh langsung positif terhadap harga saham, likuiditas berpengaruh langsung negatif terhadap harga saham, solvabilitas tidak berpengaruh langsung terhadap harga saham, profitabilitas berpengaruh langsung terhadap nilai perusahaan, likuiditas tidak berpengaruh langsung terhadap nilai perusahaan, dan solvabilitas berpengaruh langsung terhadap nilai perusahaan. Sedangkan untuk pengaruh tidak langsung didapatkan harga saham tidak mampu memediasi profitabilitas terhadap nilai perusahaan, harga saham tidak mampu memediasi likuiditas terhadap nilai perusahaan, dan harga saham tidak mampu memediasi solvabilitas terhadap nilai perusahaan.
\end{abstract}

Kata Kunci: Harga Saham, Profitabilitas, Likuiditas, Solvabilitas, Nilai Perusahaan

\begin{abstract}
The purpose of this study was to determine the role of stock price mediation in the effect of profitability, liquidity, and solvency on firm value. Stock prices use the closing price on the capital market, profitability uses return on assets (ROA), liquidity uses current ratio (CR), solvency uses debt to equity ratio (DER), while firm value uses price to book value (PBV). The population in this study are food and beverage companies listed on the Indonesia Stock Exchange (BEI) for the 2014-2019 period. The research sample used was 60 financial statement data. The sampling technique used purposive sampling. The analysis technique uses path analysis. The results showed that profitability has a positive direct effect on stock prices, liquidity has a direct negative effect on stock prices, solvency has no direct effect on stock prices,
\end{abstract}


profitability has a direct effect on firm value, liquidity has no direct effect on firm value, and solvency has a direct effect on firm value. As for the indirect effect, it is found that stock prices are not able to mediate profitability on firm value, stock prices are not able to mediate liquidity on firm value, and stock prices are not able to mediate solvency on firm value.

Keywords: Stock Price, Profitability, Liquidity, Solvency, Firm Value

\section{PENDAHULUAN}

Tujuan didirikannya perusahaan adalah mendapatkan laba atau profit untuk menjamin perusahaan berjalan sesuai visi dan misi yang telah dibuat. Perusahaan yang mendapatkan laba atau profit yang besar diharapkan memberikan keuntungan bagi pemegang saham dan dapat menarik calon investor untuk menjadi pemegang saham di perusahaan tersebut. Salah satu tolak ukur keuntungan bagi pemegang saham dapat dilihat dari nilai saham perusahaan di pasar modal. Saham adalah surat berharga yang dikeluarkan perusahaan yang berbentuk perseroan terbatas atau yang disebut emiten. Pemilik saham adalah pemilik sebagian dari perusahaan tersebut. Pada dasarnya semakin baik perusahaan dalam menghasilkan laba atau profit, maka semakin meningkatkan harga sahamnya (Sondakh, F; Tommy \& Mangantar, 2006). Calon Investor selain melihat profit yang dihasilkan perusahaan juga melihat harga saham perusahaan yang akan dibeli. Dikarenakan calon investor mengharapkan imbal balik dari investasinya nanti (Meythi; En \& Rusli, 2011). Semakin menarik saham suatu perusahaan bagi calon investor maka akan semakin tinggi pula harga saham perusahaan tersebut (Nur'aidawati, 2018). Harga saham adalah nilai saham yang terbentuk oleh kekuatan penawaran jual beli saham pada mekanisme pasar modal dan merupakan harga jual dari investor yang satu ke investor lainnya (Manoppo et al., 2017). Kondisi perekonomian saat ini yang tidak bisa diprediksi menyebabkan seluruh perusahaan bersaing untuk meningkatkan harga saham yang dimiliki dengan harapan dapat berpengaruh terhadap nilai perusahaan. Kondisi perekonomian saat ini yang tidak bisa diprediksi menyebabkan seluruh perusahaan bersaing untuk meningkatkan harga saham yang dimiliki dengan harapan dapat berpengaruh terhadap nilai perusahaan. Perusahaan yang memproduksi makanan dan minuman atau yang biasa diistilahkan dengan food and beverages juga tidak lepas dari persaingan di pasar modal.

Menurut beberapa penelitian diketahui bahwa harga saham diprediksi dapat meningkatkan nilai perusahaan. Menurut Widhiastuti \& Nugraha (2019) bahwa setiap perusahaan bertujuan memaksimalkan nilai perusahaan. Karena dengan memaksimalkan nilai perusahaan berdampak kepada kemakmuran para pemegang saham. Nilai perusahaan menggambarkan sumber dana yang dimiliki perusahaan pada periode tertentu.Sejalan yang diungkapkanAnanda (2017) nilai perusahaan adalah nilai wajar perusahaan yang menggambarkan persepsi investor terhadap emiten bersangkutan. Nilai perusahaan merupakan nilai pasar dari suatu ekuitas perusahaan ditambah nilai pasar hutang. Dengan demikian, penambahan dari jumlah ekuitas perusahaan dengan hutang perusahaan dapat mencerminkan nilai perusahaan (Chasanah \& Adhi, 2017). Hal ini sejalan yang diungkapkan oleh Tewal \& Jan (2017) semakin tinggi harga saham suatu perusahaan, maka semakin tinggi pula nilai perusahaan tersebut.

Sejumlah penelitian menjelaskan bahwa profitabilitas dianggap mampu mempengaruhi nilai perusahaan. Profitabilitas adalah kemampuan perusahaan untuk menghasilkan keuntungan dan mengukur tingkat efisiensi operasional dan efisiensi dalam menggunakan harta yang dimilikinya (Ananda, 2017). Menurut Prasetyorini (2013) perusahaan dengan tingkat pengembalian yang tinggi atas investasi perusahaan yang memperoleh laba yang besar, maka dapat dikatakan berhasil atau memiliki kinerja yang baik, sebaliknya kalau laba yang diperoleh perusahaan relatif kecil atau menurun dari periode sebelumnya, maka dapat dikatakan perusahaan kurang berhasil atau memiliki kinerja yang kurang baik. Hal yang sama juga diungkapkan Rudangga \& Sudiarta (2016) bahwa besar kecilnya profitabilitas yang dihasilkan suatu perusahaan dapat memengaruhi nilai perusahaan dengan melihat 
profitabilitas sebagai ukuran dan kinerja perusahaan yang ditunjukkan dari laba yang dihasilkan oleh perusahaan. Dengan melihat laba yang dihasilkan suatu perusahaan, jika mampu berkinerja baik sehinnga dapat menciptakan tanggapan yang positif dari investor dan juga meningkatkan harga saham dari perusahaan tersebut.Berdasarkan penelitian yang dilakukan Rudangga \& Sudiarta (2016) dan Indriyani (2017) bahwa profitabilitas berpengaruh positif dan signifikan terhadap nilai perusahaan artinya semakin tinggi efektifitas sebuah perusahaan dalam menghasilkan laba maka semakin tinggi nilai perusahaan tersebut.

Beberapa penelitian mengemukakan likuiditas dianggap mampu mempengaruhi nilai perusahaan. Sebagaimana yang dikemukakan Sunardi \& Febrianti (2020) bahwa perusahaan yang memiliki likuiditas yang baik maka dianggap memiliki kinerja yang baik oleh perusahaan. Hal ini sejalan yang dikemukakan Wljaya \& Purnawati (2014) bahwa likuiditas yang tinggi dapat mempengaruhi investor untuk berinvestasi pada perusahaan sehingga permintaan saham perusahaan akan meningkat dan kemudian harganya naik. Penelitian yang dilakukan Putra\& Lestari (2016) menyatakan bahwa likuiditas berpengaruh positif signifikan terhadap nilai perusahaan. Namun, berbanding terbalik dengan hasil penelitian Wljaya \& Purnawati (2014) bahwa likuiditas berpengaruh negatif dan signifikan terhadap nilai perusahaan artinya semakin tinggi likuiditas maka nilai perusahaan akan semakin menurun.

Beberapan penelitian menjelaskan solvabilitas dianggap mampu mempengaruhi nilai perusahaan. Menurut Misran \& Chabachib (2017) bahwa rasio solvabilitas yang menggambarkan kemampuan perusahaan untuk membayar kembali hutang yang ada dengan menggunakan modal atau ekuitas yang bersangkutan. Semakin tinggi nilai solvabilitas maka semakin tinggi pula risiko keuangan perusahaan untuk berekspansi sehingga hal ini dapat meningkatkan jumlah laba yang dihasilkan dan pada akhirnya memberikan pengaruh positif terhadap nilai perusahaan.Berdasarkan penelitian yang dilakukan Lubis; Sinaga \& Sasongko, (2017) menjelaskan bahwa solvabilitas berhubungan negatif dan tidak signifikan terhadap nilai perusahaan dikarenkan perusahaan menggunakan modal yang terdiri atas hutang sedangkan diketahui bahwa penggunaan hutang yang tinggi akan menyebabkan timbulnya kebangkrutan dan beban bunga yang semakin besar.

Tujuan penelitian ini untuk mengetahui mediasi harga saham pada pengaruh profitabilitas, likuiditas, dan solvabilitas terhadap nilai perusahaan yang dilakukan pada perusahaan makanan dan minuman periode 2014-2019 di Indonesia.

\section{LANDASAN TEORI}

\section{Nilai Perusahaan}

Menurut Ananda (2017) menjelaskan nilai perusahaan sebagai nilai wajar perusahaan yang menggambarkan persepsi investor terhadap emiten bersangkutan. Hal yang senada diungkapkan oleh Nurfauzia (2018) bahwa nilai perusahaan merupakan persepsi investor terhadap tingkat keberhasilan suatu perusahaan dalam mengelola sumber daya yang tercermin pada harga saham perusahaan. Tingginya harga saham sebuah perusahaan di pasar modal mencerminkan semakin tinggi pula nilai perusahaannya, sebaliknya rendahnya harga saham sebuah perusahaan di pasar modal maka nilai perusahaan juga semakin rendah. Hal ini menjadi penilaian bagi calon investor sebelum membeli saham perusahaan. Penelitian ini menggunakan Price Book to Value (PBV).

\section{Harga Saham}

Menurut Nur'aidawati (2018) harga saham merupakan alat yang dapat digunakan untuk memperkirakan prospek keuntungan yang didapatkan oleh investor. Harga saham secara umum dipengaruhi oleh kondisi ekonomi dan persepsi pasar terhadap kondisi perusahaan saat ini dan kondisi yang diharapkan di masa yang datang. Terdapat setidaknya 4 harga saham terdiri yaitu pertama harga pembukaan (open price), kedua harga tertinggi (high price), ketiga harga terendah (low price) dan keempat harga 
penutupan (closing price). Proses terjadinyanya harga saham dijelaskan oleh Sia \& Tjun (2011) dimulai saat perusahaan didirikan maka harga sahamnya tercermin dari jumlah modal sendiri (equity) per sahamnya, kemudian seiring berjalannya perusahaan maka harga saham terjadi dari proses demand dan supply yang terjadi di bursa efek. Jika supply lebih besar dari demand, maka menyebabkan pergerakan harga saham menurun. Demikian sebaliknya, jika supply lebih kecil daripada demand, maka harga saham bergerak naik. Penelitian ini menggunakan harga saham penutupan pada akhir periode.

\section{Profitabilitas}

Menurut Chasanah \& Adhi (2017) profitabilitas merupakan gambaran kinerja manajemen dalam mengelola perusahaan. Ukuran profitabilitas dapat berbagai macam seperti : laba operasi, laba bersih, tingkat pengembalian investasi/aktiva, dan tingkat pengembalian ekuitas. Adyani \& Sampurno (2011) menjelaskan tentang Return On Asset (ROA) adalah rasio profitabilitas yang digunakan untuk mengukur efektivitas perusahaan dalam menghasilkan keuntungan dengan memanfaatkan total asset yang dimilikinya. Hal yang sama diungkapkan Wiagustini (2010) dalam Rudangga \& Sudiarta(2016) bahwa ROA merupakan rasio yang menunjukkan hasil (return) atas jumlah aktiva yang digunakan dalam perusahaan. Penelitian ini menggunakan Return On Asset (ROA).

\section{Likuiditas}

Menurut (Putra \& Lestari, 2016) likuiditas merupakan kemampuan perusahaan untuk memenuhi kewajiban jangka pendek tepat pada waktunya. Perusahaan dikatakan likuid apabila memiliki tingkat likuiditas yang tinggi dikarenakan dana internal dengan jumlah besar yang dimiliki perusahaan terlebih dahulu digunakan untuk membiayai investasi sebelum menggunakan dana eksternal dari pihak luar berupa hutang. Sedangkan menurut Lestari \& Suryantini (2019) bahwa Current Ratio (CR) adalah rasio yang paling umum digunakan untuk mengukur likuiditas perusahaan dari kewajiban jangka pendeknya, pada rasio ini menunjukkan perbandingan antara asset lancar dengan kewajiban lancar. CR yang rendah dan tinggi kedua2nya juga berisiko, CR yang rendah mengindikasikan aset lancar yang ada kurang mampu menjamin hutang yang segera jatuh tempo, sedangkan CR yang tinggi menunjukkan adanya kelebihan aktiva lancar, yang akan mempunyai pengaruh yang tidak baik terhadap kinerja perusahaan. Penelitian ini menggunakan Current Ratio (CR).

\section{Solvabilitas}

Menurut Susilawati (2012) solvabilitas menjelaskan bagaimana kondisi perusahaan dalam melunasi kewajibannya apabila perusahaan dilikuidasi. Menurut Kasmir (2014) bahwa Debt to equity ratio (DER) merupakan rasio yang dipakai untuk membandingkan jumlah utang dengan jumlah ekuitas yang dimiliki perusahaan. Hal yang sama dijelaskan Harahap (2010) dalam Manoppo et al. (2017) bahwa Debt to equity ratio (DER) menggambarkan seberapa besar modal yang dimiliki perusahaan dalam menutupi utang-utangnya kepada pihak luar. Penelitian ini menggunakan Debt to equity ratio (DER). 


\section{Kerangka Pemikiran}

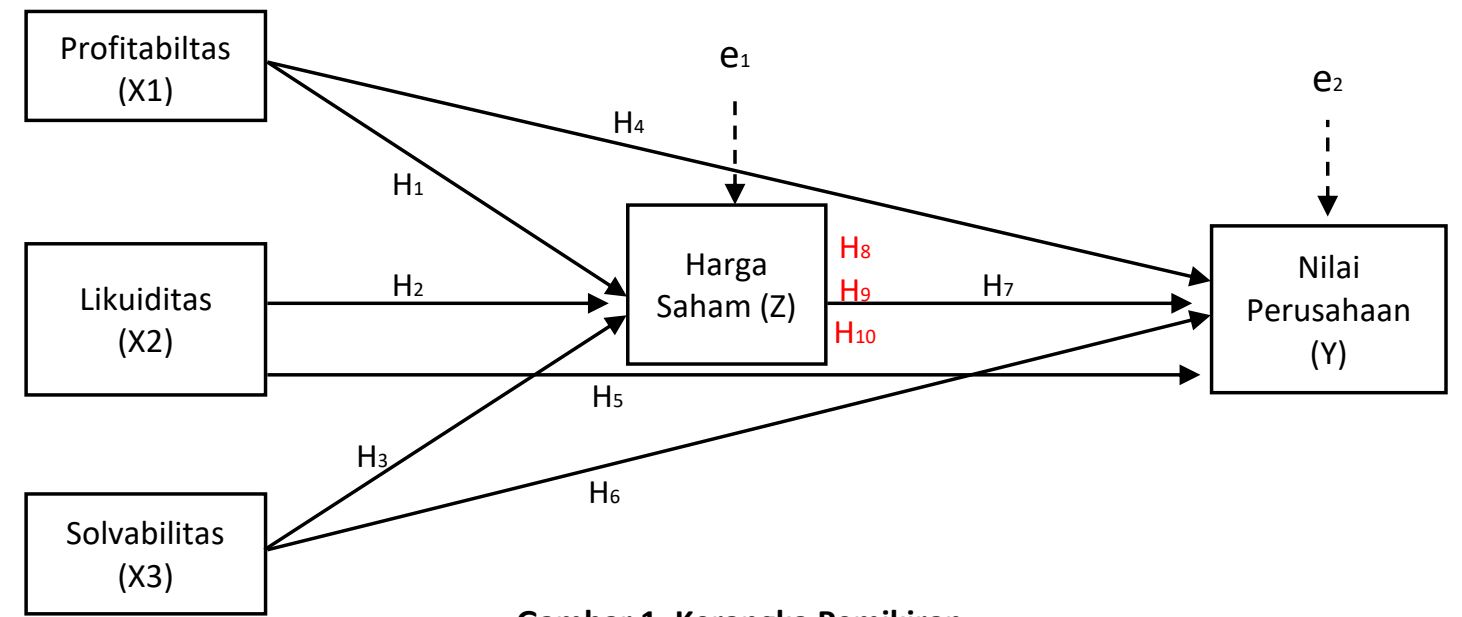

Gambar 1. Kerangka Pemikiran

Berdasarkan gambar 1. di atas dibuat 10 (hipotesis) terdiri dari 7 (tujuh) hipotesis langsung dan 3 (tiga) hipotesis tidak langsung atau hipotesis mediasi.

H1 : Profitabilitas (ROA) berpengaruh terhadap Harga Saham

H2 : Likuiditas(CR) berpengaruh terhadap Harga Saham

H3 : Solvabilitas(DER) berpengaruh terhadap Harga Saham

$\mathrm{H}_{4}$ : Profitabilitas(ROA) berpengaruh terhadap Nilai Perusahaan(PBV)

H5 : Likuiditas(CR) berpengaruh terhadap Nilai Perusahaan(PBV)

H6 : Solvabilitas(DER) berpengaruh terhadap Nilai Perusahaan (PBV)

H7 : Harga Saham berpengaruh terhadap Nilai Perusahaan (PBV)

H8: Harga Saham mampu memediasi pengaruh Profitabilitas(ROA) terhadap Nilai Perusahaan (PBV)

H9 : Harga Saham mampu memediasi pengaruh Likuiditas(CR) terhadap Nilai Perusahaan (PBV)

H10 : Harga Saham mampu memediasi pengaruh Solvabilitas(DER) terhadap Nilai Perusahaan(PBV)

\section{METODE PENELITIAN}

Data yang digunakan dalam penelitian ini adalah data sekunder yaitu data laporan keuangan yang dipublikasikan di Bursa Efek Indonesia. Populasinya sebanyak 10 perusahaan makanan dan minuman yang terdaftar di Bursa Efek Indonesia. Teknik pengambilan sampel menggunakan purposive sampling. Kriteria dalam penelitian ini adalah perusahaan makanan dan minuman yang terdaftar selama tahun 2014-2019 yang mempublikasikan laporan keuangan selama 6 tahun berturut-turut dan memiliki variabel-variabel yang diteliti. Berdasarkan kriteria tersebut maka jumlah sampel $\mathrm{N}=60$ (6 tahun $\times 10$ perusahaan). Daftar perusahaan yang dapat dilihat pada tabel 1.

Tabel 1. Nama Perusahaan

\begin{tabular}{cll}
\hline No & Kode & \multicolumn{1}{c}{ Nama Perusahaan } \\
\hline 1 & INDF & PT. Indofood Sukses Makmur Tbk \\
2 & ICBP & PT. Indofood CBP Sukses Makmur Tbk \\
3 & DLTA & PT. Delta Djakarta Tbk \\
4 & MLBI & PT. Multi Bintang Indonesia Tbk \\
5 & MYOR & PT. Mayora Indah Tbk \\
6 & ROTI & PT. Nippon Indosari Corpindo Tbk \\
7 & SKLT & PT. Sekar Laut Tbk \\
8 & STTP & PT. Siantar Top Tbk \\
9 & ULTJ & PT. Ultrajaya Milk Industry Tbk
\end{tabular}




10 CEKA PT. Wilmar Cahaya Indonesia Tbk
Sumber: Data diolah, 2021

Peneliti menggunakan teknik analisis analisis jalur atau path analysis. Analisis jalur digunakan karena analisis ini dapat menguji hipotesis asosiatif dimana antara variabel bebas/independen (biasa dinotasikan X) dan terikat/dependen (biasa dinotasikan Y) ada variabel mediasi/intervening (biasanya dinotasikan Z). Analisis ini digunakan untuk menguji pengaruh langsung dan pengaruh tidak langsung variabel $\mathrm{X}$ kepada variabel $\mathrm{Y}$ melalui perantara variabel $\mathrm{Z}$.

Pengukuran pada penelitian ini :

Profitabilitas menggunakan Return on Asset(ROA) = Laba Bersih Setelah Pajak / Total Aset(Atmaja, 2008). Likuiditas menggunakan Current Asset(CR) = Aktiva Lancar / Hutang Lancar(Suartini, S., \& Sulistiyo, 2017). Solvabilitas menggunakan Debt to Equity Ratio (DER) = Total Hutang / Total Aset (Kasmir, 2014). Nilai perusahaan menggunakan Price to Book Value (PBV) = Market Price per Share / Book Value per Share (Fakhruddin; Hadianto, 2001). Peneliti menggunakan harga penutupan (closing price) akhir tahun yang terdapat di pasar modal.

Berdasarkan penelitian diperoleh 2 (dua) persamaan sub struktural sebagai berikut :

Persamaan sub struktural 1

$Z=\rho_{\mathrm{zx} 1} \mathrm{X} 1+\rho_{\mathrm{zx} 2} \mathrm{X} 2+\rho_{\mathrm{zx} 3} \mathrm{X} 3$

Harga Saham $=\rho_{\mathrm{zx} 1}$ Profitabilitas $+\rho_{\mathrm{zx} 2}$ Likuiditas $+\rho_{\mathrm{zx} 3}$ Solvabilitas

Persamaan sub struktural 2

$\mathrm{Y}=\rho_{\mathrm{yx} 1} \mathrm{X} 1+\rho_{\mathrm{yx} 2} \mathrm{X} 2+\rho_{\mathrm{yx} 3} \mathrm{X} 3+\rho_{\mathrm{yx} 4} \mathrm{Z}$

Nilai Perusahaan $=\rho_{\mathrm{yx} 1}$ Profitabilitas $+\rho_{\mathrm{yx} 2}$ Likuiditas $+\rho_{\mathrm{yx} 3}$ Solvabilitas $+\rho_{\mathrm{yx} 4}$ Harga Saham

\section{HASIL DAN PEMBAHASAN}

Tabel 2. Harga Saham

\begin{tabular}{clcccccc}
\hline No & Kode & $\mathbf{2 0 1 4}$ & $\mathbf{2 0 1 5}$ & $\mathbf{2 0 1 6}$ & $\mathbf{2 0 1 7}$ & $\mathbf{2 0 1 8}$ & $\mathbf{2 0 1 9}$ \\
\hline 1 & INDF & 6.750 & 5.175 & 7.925 & 7.625 & 7.450 & 7.925 \\
2 & ICBP & 6.550 & 6.738 & 8.575 & 8.900 & 10.450 & 11.150 \\
3 & DLTA & 7.800 & 5.200 & 5.000 & 4.590 & 5.500 & 6.800 \\
4 & MLBI & 11.950 & 8.200 & 11.750 & 13.675 & 16.000 & 15.500 \\
5 & MYOR & 836 & 1.220 & 1.645 & 2.020 & 2.620 & 2.050 \\
6 & ROTI & 1.385 & 1.265 & 1.600 & 1.275 & 1.200 & 1.300 \\
7 & SKLT & 300 & 370 & 308 & 1.100 & 1.500 & 1.610 \\
8 & STTP & 2.880 & 3.015 & 3.190 & 4.360 & 3.750 & 4.500 \\
9 & ULTJ & 930 & 986 & 1.143 & 1.295 & 1.350 & 1.680 \\
10 & CEKA & 750 & 675 & 1.350 & 1.290 & 1.375 & 1.670 \\
\hline
\end{tabular}

Sumber : $B E I, 2021$

Berdasarkan tabel 2 di atas menunjukkan daftar harga saham dalam satuan mata uang rupiah dari 10 perusahaan periode 2014-2019. Harga saham diambil dari harga saham penutupan pada akhir tahun. Harga saham terendah Rp. 300 dimiliki oleh PT. Sekar Laut Tbk. tahun 2014, dan harga saham tertinggi Rp. 16.000 dimiliki oleh PT. Multi Bintang Indonesia Tbk. tahun 2018. 


\section{Analisis Deskriptif}

Tabel 3. Hasil Uji Statistik Deskriptif

\begin{tabular}{lccccc}
\hline & N & Minimum & Maximum & Mean & Std. Deviation \\
\hline Nilai Perusahaan & 60 & .16 & 45.47 & 6.0057 & 9.12509 \\
Profitabilitas & 60 & 2.89 & 52.67 & 13.4297 & 10.82648 \\
Likuiditas & 60 & .51 & 8.64 & 2.6668 & 1.88775 \\
Solvabilitas & 60 & .16 & 3.03 & .8448 & .54138 \\
Harga Saham & 60 & 300 & 16000 & 4449.52 & 4069.011 \\
Valid N (listwise) & 60 & & & & \\
\hline
\end{tabular}

Sumber : Data diolah, 2021

Dari hasil uji statistik deskriptif di atas, menunjukkan bahwa nilai perusahaan memiliki rentang nilai dari o,16 hingga 45,47. Nilai perusahaan terendah dimiliki PT. Delta Djakarta Tbk pada tahun 2014 dan nilai perusahaan tertinggi dimiliki PT. Multi Bintang Indonesia Tbk pada tahun 2014. Rata-rata nilai perusahaan 6,0057 dan standar deviasi sebesar 9,12509. Variabel profitabilitas memiliki rentang nilai dari 2,89 hingga 52,67. Profitabilitas terendah dimiliki PT. Nippon Indosari Corporindo Tbk pada tahun 2018 dan profitabilitas tertinggi dimiliki PT. Multi Bintang Indonesia Tbk pada tahun 2017. Rata-rata profitabilitas sebesar 12,4297 dan standar deviasi sebesar 10,82648.

Variabel likuiditas memiliki rentang nilai dari 0,51 hingga 8,64. Likuiditas terendah dimiliki oleh PT. Multi Bintang Indonesia pada tahun 2014 dan likuiditas tertinggi dimiliki oleh PT. Delta Djakarta Tbk pada tahun 2017. Rata-rata likuiditas sebesar 2,6668 dan standar deviasi sebesar 1,88775. Variabel solvabilitas memiliki rentang nilai dari 0,16 hingga 3,03. Solvabilitas terendah dimiliki oleh PT. Ultrajaya Milk Industry Tbk pada tahun 2018 dan sovabilitas tertinggi dimiliki oleh PT. Multi Bintang Indonesia Tbk pada tahun 2014. Rata-rata solvabilitas sebesar 0,8448 dan standar deviasi sebesar 0.54138. Variabel harga saham memiliki rentang nilai dari 300 hingga 16.000. Harga saham terendah dimiliki oleh PT. Sekar Laut Tbk pada tahun 2014 dan harga saham tertinggi dimiliki oleh PT. Multi Bintang Indonesia Tbk pada tahun 2018.

\section{Uji Normalitas}

Tabel 4. Hasil Uji Normalitas

\begin{tabular}{llr}
\hline & & $\begin{array}{r}\text { Unstandardized } \\
\text { Residual }\end{array}$ \\
\hline $\mathrm{N}$ & Mean & 60 \\
Normal Parameters & a & .0000000 \\
& Std. Deviation & 4.05791447 \\
Most Extreme Differences & Absolute & .162 \\
& Positive & .162 \\
Kolmogorov-Smirnov Z & Negative & -.082 \\
Asymp. Sig. (2-tailed) & & 1.258 \\
\hline a. Test distribution is Normal. & .085 \\
Sumber : Data diolah, 2021 &
\end{tabular}


Dari hasil uji normalitas menggunakan Kolmogorov-Smirnov Z untuk semua variabel diperoleh nilai Asymp. Sig. (2-tailed) sebesar 0,085. Nilai Asymp. Sig. (2-tailed) lebih dari 0,05 menunjukkan variabel nilai perusahaan, profitabilitas, likuiditas, solvabilitas dan harga saham berdistribusi normal.

\section{Uji Multikolinearitas}

Tabel 5. Hasil Uji Multikolinearitas

\begin{tabular}{|c|c|c|c|}
\hline \multirow[b]{2}{*}{ Model } & & \multicolumn{2}{|c|}{$\begin{array}{c}\text { Collinearity } \\
\text { Statistics }\end{array}$} \\
\hline & & Tolerance & VIF \\
\hline \multirow[t]{5}{*}{1} & (Constant) & & \\
\hline & Profitabilitas & .375 & 2.668 \\
\hline & Likuiditas & .379 & 2.640 \\
\hline & Solvabilitas & .402 & 2.485 \\
\hline & Harga Saham & .421 & 2.377 \\
\hline
\end{tabular}

Berdasarkan nilai Tolerance dan VIF dari tabel 5 di atas, diketahui nilai Tolerance $>0.1$ dan nilai VIF kurang dari 10. Maka dapat disimpulkan bahwa tidak terjadi gejala multikolinearitas.

\section{Uji Heterokedastisitas}

Tabel 6. Hasil Uji Heterokedastisitas

\begin{tabular}{|c|c|c|c|c|c|c|c|}
\hline & & & $\begin{array}{l}\text { Absolut } \\
\text { Residu }\end{array}$ & Profitabilitas & Likuiditas & Solvabilitas & Harga Saham \\
\hline \multirow[t]{3}{*}{$\begin{array}{l}\text { Spearman's } \\
\text { rho }\end{array}$} & $\begin{array}{l}\text { Absolut } \\
\text { Residu }\end{array}$ & $\begin{array}{l}\text { Correlation } \\
\text { Coefficient }\end{array}$ & 1.000 & -.140 & .004 & .078 & -.122 \\
\hline & & Sig. (2-tailed) & . & .286 & .977 & .553 & .352 \\
\hline & & $\mathrm{N}$ & 60 & 60 & 60 & 60 & 60 \\
\hline
\end{tabular}

*. Correlation is significant at the 0.05

level (2-tailed).

**. Correlation is significant at the 0.01

level (2-tailed).

Sumber : Data diolah, 2021

Berdasarkan hasil uji heterokedastisitas tabel 6 di atas dengan metode Rho Spearman menunjukkan koefisien korelasi rho spearman antara profitabilitas dengan absolut residu sebesar -0,140 dengan sig 0,286 . Oleh karena nilai sig tersebut lebih besar dari 0,05 maka dapat disimpulkan tidak terjadi heterokedastisitas untuk variabel profitabilitas. Koefisien korelasi rho spearman antara likuiditas dengan absolut residu sebesar 0,004 dengan sig 0,977. Oleh karena nilai sig tersebut lebih besar dari 0,05 maka dapat disimpulkan tidak terjadi heterokedastisitas untuk variabel likuditas.

Koefisien korelasi rho spearman antara solvabilitas dengan absolut residu sebesar 0,078 dengan sig 0,553 . Oleh karena nilai sig tersebut lebih besar dari 0,05 maka dapat disimpulkan tidak terjadi heterokedastisitas untuk variabel solvabilitas. Koefisien korelasi rho spearman antara harga saham dengan absolut residu sebesar -0,122 dengan sig 0,352. Oleh karena nilai sig tersebut lebih besar dari 0,05 maka dapat disimpulkan tidak terjadi heterokedastisitas untuk variabel harga saham. 


\section{Uji Autokorelasi}

Tabel 7. Hasil Uji Autokorelasi

\begin{tabular}{lccccr}
\hline Model & R & R Square & $\begin{array}{c}\text { Adjusted R } \\
\text { Square }\end{array}$ & $\begin{array}{c}\text { Std. Error of the } \\
\text { Estimate }\end{array}$ & Durbin-Watson \\
\hline 1 & $.880^{\text {a }}$ & .774 & .757 & 4.12022 & 1.936 \\
a. Predictors: (Constant), Harga Saham, Likuiditas, Solvabilitas, Profitabilitas & \\
b. Dependent Variable: Nilai Perusahaan & & & \\
Sumber : Data diolah, 2021 &
\end{tabular}

Dari hasil di atas didapatkan nilai Durbin Watson 1.936. Kemudian nilai dW tersebutkan dibandingkan dengan nilai $\mathrm{dL}=1,443 \mathrm{dan} \mathrm{dU}=1,7274$ pada tabel durbin Watson dengan $\mathrm{k}=4 \mathrm{n}=60$. Dengan kriteria $\mathrm{dU}$ $\leq \mathrm{dW} \leq 4$-dU, maka 1,7274 $\leq 1,936 \leq 2,2726$. Maka dapat disimpulkan bahwa tidak ada autokorelasi.

\section{Uji Analisa Jalur (Path Analysis)}

\section{Persamaan sub struktural 1}

Tabel 8. Hasil Output Persamaan Sub Struktural 1

\begin{tabular}{|c|c|c|c|c|c|c|}
\hline \multirow[b]{2}{*}{ Model } & & \multicolumn{5}{|c|}{ Standardized } \\
\hline & & B & Std. Error & $\frac{\text { Coefficients }}{\text { Beta }}$ & $\mathbf{T}$ & Sig. \\
\hline \multirow[t]{4}{*}{1} & (Constant) & 2700.962 & 1147.667 & & 2.353 & .022 \\
\hline & Profitabilitas & 289.762 & 34.345 & .782 & 8.437 & .000 \\
\hline & Likuiditas & -713.100 & 274.571 & -.338 & -2.597 & .012 \\
\hline & Solvabilitas & -1045.416 & 944.153 & -.147 & -1.107 & .273 \\
\hline
\end{tabular}

a. Dependent Variable: Harga Saham

Sumber : Data diolah, 2021

Berdasarkan tabel 8 di atas persamaan sub struktural 1 diambil dari kolom Beta sehingga dapat dibuat persamaan Harga Saham $=0,782$ Profitabilitas-0,338Likuiditas-0,147Solvabilitas. Pengaruh langsung Profitabilitas terhadap Harga Saham sebesar 0,782 dengan nilai Sig 0,000 artinya Profitabilitas berpengaruh signifikan terhadap Harga Saham. Pengaruh langsung Likuiditas terhadap Harga Saham sebesar -0,338 dengan nilai Sig 0,012 artinya Likuiditas berpengaruh negatif signifikan terhadap Harga Saham. Pengaruh langsung Solvabilitas terhadap Harga Saham sebesar -0,147 dengan nilai Sig. 0,273 artinya Solvabilitas tidak berpengaruh terhadap Harga Saham.

Tabel 9. Koefisien Determinasi Persamaan Sub Struktural 1

\begin{tabular}{llrrr}
\hline Model & R & R Square & \multicolumn{1}{c}{$\begin{array}{c}\text { Adjusted R } \\
\text { Square }\end{array}$} & $\begin{array}{c}\text { Std. Error of the } \\
\text { Estimate }\end{array}$ \\
\hline 1 & $.769^{\mathrm{a}}$ & .592 & .570 & 2324.64572
\end{tabular}

a. Predictors: (Constant), Solvabilitas, Profitabilitas, Likuiditas Sumber : Data diolah, 2021

Besarnya nilai R Square yang terdapat pada tabel 8 sebesar 0,592 menunjukkan bahwa kontribusi atau sumbangan pengaruh Profitabilitas, Likuiditas dan Solvabilitas terhadap Harga Saham sebesar 59,2\% sementara sisanya $41,8 \%$ merupakan kontribusi dari variabel-variabel lain yang tidak dimasukkan dalam penelitian ini. Sementara e1 $=\mathrm{V}(1-0,592)=0,638$. 


\section{Persamaan sub struktural 2}

Tabel 10. Hasil Output Persamaan Sub Struktural 2

\begin{tabular}{|c|c|c|c|c|c|c|}
\hline & & \multicolumn{2}{|c|}{$\begin{array}{l}\text { Unstandardized } \\
\text { Coefficients }\end{array}$} & \multirow{2}{*}{$\begin{array}{c}\text { Standardized } \\
\text { Coefficients } \\
\text { Beta }\end{array}$} & \multirow[b]{2}{*}{$\mathbf{T}$} & \multirow[b]{2}{*}{ Sig. } \\
\hline \multicolumn{2}{|c|}{ Model } & B & Std. Error & & & \\
\hline \multirow[t]{5}{*}{1} & (Constant) & -7.162 & 2.134 & & -3.356 & .001 \\
\hline & Profitabilitas & .400 & .092 & .457 & 4.334 & .000 \\
\hline & Likuiditas & .074 & .516 & .015 & .144 & .886 \\
\hline & Solvabilitas & 7.955 & 1.692 & .473 & 4.702 & .000 \\
\hline & Harga Saham & .001 & .000 & .233 & 2.300 & .025 \\
\hline
\end{tabular}

a. Dependent Variable: Nilai Perusahaan

Sumber : Data diolah, 2021

Berdasarkan tabel 10 di atas persamaan sub struktural 2 diambil dari kolom Beta sehingga dapat dibuat persamaan Nilai Perusahaan $=0,457$ Profitabilitas $+0,015$ Likuiditas $+0,473$ Solvabilitas $+0,233$ Harga Saham. Pengaruh langsung Profitabilitas terhadap Nilai Perusahaan sebesar 0,457 dengan nilai Sig 0,000 artinya Profitabilitas berpengaruh signifikan terhadap Nilai Perusahaan. Pengaruh langsung Likuiditas terhadap Nilai Perusahaan sebesar 0,015 dengan nilai Sig 0,886 artinya Likuiditas tidak berpengaruh terhadap Nilai Perusahaan. Pengaruh langsung Solvabilitas terhadap Nilai Perusahaan sebesar 0,473 dengan nilai Sig. 0,00 artinya Solvabilitas berpengaruh signifikan terhadap Nilai Perusahaan. Pengaruh langsung Harga Saham terhadap Nilai Perusahaan sebesar 0,233 dengan nilai Sig. 0,025 artinya Harga Saham berpengaruh signifikan terhadap Nilai Perusahaan.

Tabel 11. Koefisien Determinasi Persamaan Sub Struktural 2

\begin{tabular}{llrrr}
\hline Model & R & R Square & \multicolumn{1}{c}{$\begin{array}{c}\text { Adjusted R } \\
\text { Square }\end{array}$} & $\begin{array}{c}\text { Std. Error of the } \\
\text { Estimate }\end{array}$ \\
\hline 1 & $.880^{\mathrm{a}}$ & .774 & .757 & 4.12022 \\
\hline
\end{tabular}

a. Predictors: (Constant), Harga Saham, Likuiditas, Solvabilitas, Profitabilitas

Sumber : Data diolah, 2021

Besarnya nilai R Square yang terdapat pada tabel 11 sebesar 0,774 menunjukkan bahwa kontribusi atau sumbangan pengaruh Profitabilitas, Likuiditas, Solvabilitas dan Harga Saham terhadap Nilai Perusahaan sebesar $77,4 \%$ sementara sisanya $23,6 \%$ merupakan kontribusi dari variabel-variabel lain yang tidak dimasukkan dalam penelitian ini. Sementara e1 $=\mathrm{V}(1-0,774)=0,475$.

Pengaruh tidak langsung Profitabilitias terhadap Nilai Perusahaan dengan mediasi Harga Saham sebesar koefisien jalur $=0,782 \times 0,233=0,182$. Koefisien jalur 0,182 $<0,447$ artinya Harga Saham tidak mampu memediasi pengaruh Profitabilitas terhadap Nilai Perusahaan. Pengaruh tidak langsung Likuiditas terhadap Nilai Perusahaan dengan mediasi Harga Saham sebesar koefisien jalur $=-0,338 \times 0,233=-$ 0,078. Koefisien jalur $-0,078<0,015$ artinya Harga Saham tidak mampu memediasi pengaruh Likuiditas terhadap Nilai Perusahaan. Pengaruh tidak langsung Solvabilitas terhadap Nilai Perusahaan dengan mediasi Harga Saham sebesar koefisien jalur $=-0,147 \times 0,233=-0,034$. Koefisien jalur $-0,034<0,473$ artinya Harga Saham tidak mampu memediasi pengaruh Solvabilitas terhadap Nilai Perusahaan. 


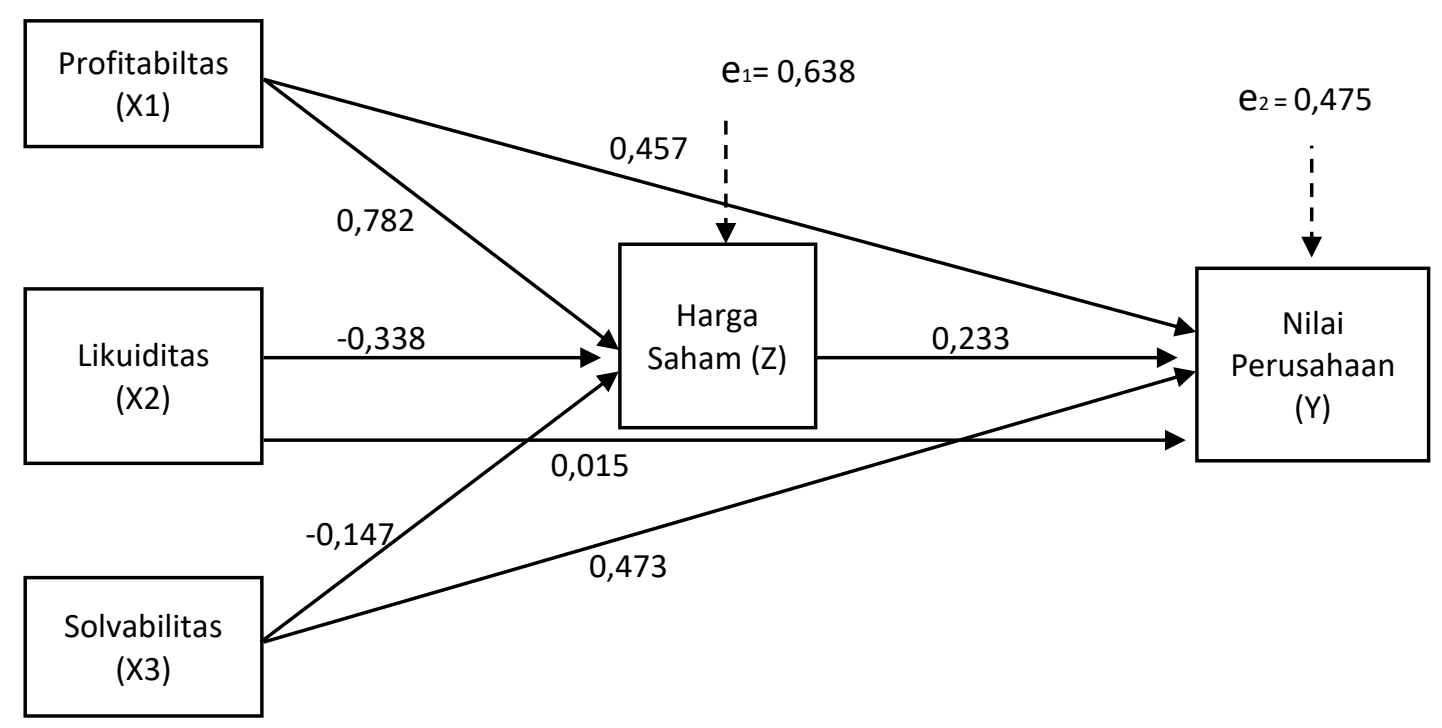

Gambar 2. Diagram Jalur

\section{Pembahasan}

\section{H1 : Profitabilitas terhadap Harga Saham}

Berdasarkan hasil output persamaan sub struktural 1, diperoleh t hitung 8,437 dan nilai Signifikansi $(0,000<0,05)$. Dapat disimpulkan bahwa Profitabilitas berpengaruh signifikan terhadap Harga Saham. Hal ini menjelaskan semakin tinggi laba bersih yang didapatkan dari penggunaan asset yang dimiliki perusahaan maka dapat meningkatkan harga saham perusahaan. Return on asset menjadi daya tarik bagi investor yang dapat memicu kenaikan harga saham di bursa. Hal ini sesuai dengan penelitian Sondakh et al. (2015), dan Nur'aidawati (2018). Berdasarkan penjelasan tersebut maka H1 diterima.

\section{H2 : Likuiditas terhadap Harga Saham}

Berdasarkan hasil output persamaan sub struktural 1, diperoleh t hitung -2,597 dan nilai Signifikansi $(0,012<0,05)$. Dapat disimpulkan bahwa Likuiditas berpengaruh negatif signifikan terhadap Harga Saham.Artinya semakin tinggi nilai current ratio maka dapat menurunkan harga saham karena dimungkinkan semakin tinggi hutang jangka pendek yang dimiliki oleh perusahaan walaupun diikuti semakin tinggi pula asset lancar yang menjadi jaminan. Hal ini dimungkinkan karena Likuiditas yang diwakili dengan current ratio memiliki keterbatasan untuk meningkatkan minat investor yang terhadap harga saham. Hal ini sesuai dengan penelitian Manoppo, V. C. O; Tewal \& Jan (2017) dan Sia \& Tjun (2011) yang menyatakan current ratio berpengaruh negatif terhadap harga saham. Berdasarkan penjelasan tersebut maka $\mathrm{H} 2$ diterima.

\section{H3 : Solvabilitas terhadap Harga Saham}

Berdasarkan hasil output persamaan sub struktural 1, diperoleh t hitung -1,107 dan nilai Signifikansi $(0,273>0,05)$. Dapat disimpulkan bahwa Solvabilitas tidak berpengaruh terhadap Harga Saham. Artinya investor tidak memperhatikan besarnya hutang dan modal yang dimiliki oleh perusahaan. Semakin besarnya hutang perusahaan akan meningkatkan resiko atas berkurangnya laba yang dihasilkan perusahaan serta mengurangi ekuitas secara keseluruhan. Karena sebagian laba digunakan untuk melunasi hutang tersebut yang dapat menimbulkan persepsi negatif kepada investor. Hal ini sejalan dengan penelitian Lestari \& Suryantini (2019) dan Valintino \& Sularto (2013). Berdasarkan penjelasan tersebut maka $\mathrm{H} 3$ ditolak. 


\section{H4 : Profitabilitas terhadap Nilai Perusahaan}

Berdasarkan hasil output persamaan sub struktural 2, diperoleh t hitung 4,334 dan nilai Signifikansi $(0,000<0,05)$. Dapat disimpulkan bahwa Profitabilitas berpengaruh terhadap Nilai Perusahaan. Hal ini menjelaskan semakin tinggi laba bersih yang didapatkan dari penggunaan asset yang dimiliki perusahaan maka dapat meningkatkan nilai perusahaan. Ini membuktikan bahwa investor tertarik pada perusahaan yang profitabilitasnya baik. Hal ini sesuai dengan penelitian Hermuningsih (2013), Putra \& Lestari (2016) dan Purwanto \& Agustin (2017). Berdasarkan penjelasan tersebut maka H4 diterima.

\section{H5 : Likuiditas terhadap Nilai Perusahaan}

Berdasarkan hasil output persamaan sub struktural 2, diperoleh t hitung 0,144 dan nilai Signifikansi $(0,888>0,05)$. Dapat disimpulkan bahwa Likuiditas tidak berpengaruh terhadap Nilai Perusahaan. Hal ini menjelaskan kemampuan perusahaan dalam melunasi kewajiban jangka pendek dengan aktiva lancar yang dimiliki tidak dapat mempengaruhi nilai perusahaan. Hal ini dimungkinkan karena perusahaan mampu menjaga jumlah hutang jangka pendek pada jumlah yang wajar dan tepat waktu dalam pembayaran, sehingga tidak diperlukan seluruh aktiva lancar sebagai jaminan sehingga nilai perusahaan cenderung tetap selama beberapa periode. Penelitian ini sesuai dengan penelitian Manoppo et al. (2017). Berdasarkan penjelasan tersebut maka H5 ditolak.

\section{H6 : Solvabilitas terhadap Nilai Perusahaan}

Berdasarkan hasil output persamaan sub struktural 2, diperoleh t hitung 4,702 dan nilai Signifikansi $(0,000<0,05)$. Dapat disimpulkan bahwa Solvabilitas berpengaruh terhadap Nilai Perusahaan. Artinya semakin tinggi perusahaan menggunakan dana yang berasal dari hutang maka semakin tinggi nilai perusahaan. Hal ini sesuai dengan penelitian Rudangga \& Sudiarta (2016). Berdasarkan penjelasan tersebut maka $\mathrm{H} 6$ diterima.

\section{H7 : Harga Saham terhadap Nilai Perusahaan}

Berdasarkan hasil output persamaan sub struktural 2, diperoleh t hitung 2,300 dan nilai Signifikansi $(0,025<0,05)$. Dapat disimpulkan bahwa Harga Saham berpengaruh terhadap Nilai Perusahaan. Hal ini sejalan dengan penelitian Saputra \& Martha (2019) bahwa nilai perusahaan merupakan tingkat keberhasilan Manajemen perusahaan dalam menjalankan perusahaan, mengelola sumber daya yang tercermin pada harga saham pada akhir tahun. Berdasarkan penjelasan tersebut maka $\mathrm{H} 7$ diterima.

\section{H8 : Harga Saham sebagai mediasi pengaruh Profitabilitas terhadap Nilai Perusahaan}

Diketahui pengaruh langsung yang diberikan Profitabilitas terhadap Nilai Perusahaan sebesar 0,457. Sedangkan pengaruh tidak langsung Profitabilitas melalui Harga Saham terhadap Nilai Perusahaan yaitu : 0,782 x 0,233 =0,182. Maka pengaruh total yang diberikan Profitabilitas terhadap Nilai Perusahaan adalah pengaruh langsung ditambah pengaruh tidak langsung yaitu : 0,457 +0,182 =0,639. Berdasarkan perhitungan di atas diketahui bahwa nilai pengaruh langsung sebesar 0,457 dan pengaruh tidak langsung 0,182 yang berarti bahwa nilai pengaruh tidak langsung lebih besar dibandingkan dengan nilai pengaruh langsung. Hal ini menunjukkan bahwa Harga Saham tidak mampu memediasi pengaruh Profitabilitas terhadap Nilai Perusahaan. Berdasarkan penjelasan tersebut maka H8 ditolak.

\section{H9 : Harga Saham sebagai mediasi pengaruh Likuiditas terhadap Nilai Perusahaan}

Diketahui pengaruh langsung yang diberikan Likuiditas terhadap Nilai Perusahaan sebesar 0,015. Sedangkan pengaruh tidak langsung Likuiditas melalui Harga Saham terhadap Nilai Perusahaan yaitu : $0,338 \times 0,233=-0,078$. Maka pengaruh total yang diberikan Likuiditas terhadap Nilai Perusahaan adalah pengaruh langsung ditambah pengaruh tidak langsung yaitu : $0,015+(0,078)=-0,063$. Berdasarkan perhitungan di atas diketahui bahwa nilai pengaruh langsung sebesar 0,015 dan pengaruh tidak langsung -0,063 yang berarti bahwa nilai pengaruh tidak langsung lebih besar dibandingkan dengan nilai 
pengaruh langsung. Hal ini menunjukkan bahwa Harga Saham tidak mampu memediasi pengaruh Likuiditas terhadap Nilai Perusahaan. Berdasarkan penjelasan tersebut maka H9 ditolak.

\section{H10 : Harga Saham sebagai mediasi pengaruh Solvabilitas terhadap Nilai Perusahaan}

Diketahui pengaruh langsung yang diberikan Solvabilitas terhadap Nilai Perusahaan sebesar 0,473. Sedangkan pengaruh tidak langsung Solvabilitas melalui Harga Saham terhadap Nilai Perusahaan yaitu : $0,147 \times 0,233=-0,034$. Maka pengaruh total yang diberikan Solvabilitas terhadap Nilai Perusahaan adalah pengaruh langsung ditambah pengaruh tidak langsung yaitu : $0,473+(0,034)=0,439$. Berdasarkan perhitungan di atas diketahui bahwa nilai pengaruh langsung sebesar 0,473 dan pengaruh tidak langsung -0,034 yang berarti bahwa nilai pengaruh tidak langsung lebih besar dibandingkan dengan nilai pengaruh langsung. Hal ini menunjukkan bahwa Harga Saham tidak mampu memediasi pengaruh Solvabilitas terhadap Nilai Perusahaan. Berdasarkan penjelasan tersebut maka H10 ditolak.

\section{SIMPULAN}

Berdasarkan hasil penelitian dengan menggunakan analisis jalur (path analysis), dapat disimpulkan yakni: 1)Profitabilitas berpengaruh positif signifikan terhadap Harga Saham, 2)Likuiditas berpengaruh negatif signifikan terhadap Harga Saham, 3)Solvabilitas tidak berpengaruh terhadap Harga Saham, 4)Profitabilitas berpengaruh positif terhadap Nilai Perusahaan, 5)Likuiditas tidak berpengaruh terhadap Nilai Perusahaan, 6)Solvabilitas berpengaruh positif terhadap Nilai Perusahaan, 7)Harga Saham berpengaruh positif terhadap Nilai Perusahaan,8)Harga Saham tidak mampu memediasi pengaruh Profitabilitas terhadap Nilai Perusahaan, 9)Harga Saham tidak mampu memediasi pengaruh Likuiditas terhadap Nilai Perusahaan, 10)Harga Saham tidak mampu memediasi pengaruh Solvabilitas terhadap Nilai Perusahaan. Sehingga disimpulkan bahwa variabel Harga Saham tidak mampu menjadi variabel intervening dalam penelitian ini.

Berdasarkan kesimpulan di atas, maka saran yang dapat diberikan yakni: 1) Bagi pihak Manajemen agar memperhatikan variabel Profitabilitas, Likuiditas terhadap Harga Saham karena terbukti berpengaruh signifikan. Serta memperhatikan variabel Profitabilitas, Solvabilitas dan Harga Saham karena berdasarkan penelitian terbukti secara bersama-sama berpengaruh signifikan terhadap nilai perusahaan. 2) Diharapkan pada penelitian berikutnya dapat membuktikan harga saham mampu menjadi variabel intervening.

\section{REFERENSI}

Adyani, L. R., \& Sampurno, D. R. D. (2011). Analisis faktor-faktor yang mempengaruhi profitabilitas (ROA). Jurnal Dinamika Ekonomi Pembangunan, 7(1), 46-54.

Ananda, N. A. (2017). Pengaruh Profitabilitas Dan Struktur Modal Terhadap Nilai Perusahaan. Jurnal Ekonomi Dan Bisnis Indonesia, 2(1). https://doi.org/10.37673/jebi.v2i1.50

Atmaja, L. S. (2008). Teori dan Praktik MANAJEMEN KEUANGAN (I). CV. ANDI OFFSET.

Chasanah, A. N., \& Adhi, D. K. (2017). Profitabilitas, Struktur Modal dan Likuiditas Pengaruhnya Terhadap Nilai Perusahaan Pada Perusahaan Real Estate yang Listed di BEI (Profitability, Capital Structure and Liquidity Influence on Corporate Value on Listed Real Estate Companies in BEI, 201220. Fokus Ekonomi, 12(2), 131-146.

Fakhruddin; Hadianto, S. (2001). Perangkat dan Model Analisis Investasi di Pasar Modal, Buku satu. Elex Media Komputindo.

Hermuningsih, S. (2013). Pengaruh profitabilitas, growth opportunity, struktur modal terhadap nilai perusahaan pada perusahaan publik di Indonesia. Buletin Ekonomi Moneter Dan Perbankan, 16(2), 
127-148.

Indriyani, E. (2017). Pengaruh ukuran perusahaan dan profitabilitas terhadap nilai perusahaan. Akuntabilitas: Jurnal Ilmu Akuntansi, 10(2), 333-348.

Kasmir. (2014). Analisis Laporan Keuangan (7th ed.). Rajawali Pers.

Lestari, I. S. D., \& Suryantini, N. P. S. (2019). PENGARUH CR, DER, ROA, DAN PER TERHADAP HARGA SAHAM PADA PERUSAHAAN FARMASI DI BEI. E-Jurnal Manajemen Universitas Udayana, 8(3), 1844. https://doi.org/10.24843/ejmunud.2019.v08.i03.p24

Lubis, Ignatius Leonardus; Sinaga, B. M., \& Sasongko, H. (2017). Pengaruh Profitabilitas, Sruktur Modal, Dan Likuiditas Terhadap Nilai Perusahaan. Jurnal Aplikasi Bisnis Dan Manajemen (JABM), 3(3), 458.

Manoppo, V. C. O., Tewal, B., \& Jan, A. B. H. (2017). Pengaruh Current Ratio, Der, Roa Dan Npm Terhadap Harga Saham Pada Perusahaan Food and Beverages Yang Terdaftar Di Bei (Periode 2013-2015). Jurnal Riset Ekonomi, Manajemen, Bisnis Dan Akuntansi, 5(2). https://doi.org/10.35794/emba.v5i2.16399

Meythi; En, T. K., \& Rusli, L. (2011). Pengaruh Likuiditas dan Profitabilitas Terhadap Harga Saham Perusahaan Manufaktur yang Terdaftar di Bursa Efek Indonesia. Jurnal Bisnis Manajemen Dan Ekonomi, 10(2), 2671-2684.

Misran, M., \& Chabachib, M. (2017). Analisis Pengaruh Der Cr Dan Tato Terhadap Pbv Dengan Roa Sebagai Variabel Intervening (Studi Pada Perusahaan Properti Dan Real Estate Yang Terdaftar Pada Bei Tahun 2011-2014). Diponegoro Journal Of Management, 6(1), 203-215.

Nur'aidawati, S. (2018). Pengaruh Current Ratio (CR), Total Asset Turnover (TATO), Debt to Equity Ratio (DER) dan Return On Asset (ROA) Terhadap Harga Saham dan Dampaknya Pada Nilai Perusahaan (Studi Kasus Pada Sepuluh Bank Terbesar Yang Terdaftar di Bursa Efek Indonesia Periode. Jurnal Sekuritas (Saham, Ekonomi, Keuangan Dan Investasi), 1(3).

Nurfauzia, A. (2018). PENGARUH INTELLECTUAL CAPITAL PADA NILAI PERUSAHAAN DENGAN KINERJA KEUANGAN SEBAGAI VARIABEL INTERVENING (Studi pada Industri Barang Konsumsi yang terdaftar di Bursa Efek Indonesia 2010-2016). Universitas Islam Indonesia.

Prasetyorini, B. F. (2013). Pengaruh ukuran perusahaan, leverage, price earning ratio dan profitabilitas terhadap nilai perusahaan. Jurnal IImu Manajemen (JIM), 1(1).

Purwanto, P., \& Agustin, J. (2017). Financial performance towards value of firms in basic and chemicals industry. European Research Studies Journal, 20(2), 443-460. https://doi.org/10.35808/ersj/652

Putra, A. A. N. D. A., \& Lestari, P. V. (2016). Pengaruh Kebijakan Dividen, Likuiditas, Profitabilitas dan Ukuran Perusahaan Terhadap Nilai Perusahaan. E-Jurnal Manajemen Universitas Udayana, 5(7).

Rudangga, I. G. N. G., \& Sudiarta, G. M. (2016). Pengaruh ukuran perusahaan, leverage, dan profitabilitas terhadap nilai perusahaan. E-Jurnal Manajemen Universitas Udayana, 5(7).

Saputra, J., \& Martha, L. (2019). Analisis Kinerja Keuangan Dan Nilai Perusahaan, Serta Pengaruhnya Terhadap Harga Saham.

Sia, V. L. R., \& Tjun, L. T. (2011). Pengaruh current ratio, earnings per share, dan price earnings ratio terhadap harga saham. Jurnal Akuntansi, 3(2), 136-158.

Sondakh, F; Tommy, P., \& Mangantar, M. (2006). CURRENT RATIO, DEBT TO EQUITY RATIO, RETURN ON ASSET, RETURN ON EQUITY PENGARUHNYA TERHADAP HARGA SAHAM PADA INDEKS LQ 45 DI BEI PERIODE 2010-2014. Encyclopedia of Production and Manufacturing Management, 3(2), 138-138. https://doi.org/10.1007/1-4020-0612-8_202

Suartini, S., \& Sulistiyo, H. (2017). Praktikum Analisis Laporan Keuangan Bagi Mahasiswa dan Praktikan (1st ed.). Mitra Wacana Media. 
Sunardi, N., \& Febrianti, F. (2020). Likuiditas dan Kebijakan Hutang Pengaruhnya terhadap Kinerja Perusahaan dan Dampaknya Terhadap Nilai Perusahaan pada Industri Sektor Telekomunikasi di Indonesia. JIMF (Jurnal Ilmiah Manajemen Forkamma), 3(3). https://doi.org/10.32493/frkm.v3i3.6206

Susilawati, C. D. K. (2012). Analisis Perbandingan Pengaruh Likuiditas, Solvabilitas, dan Profitabilitas Terhadap Harga Saham pada Perusahaan LQ 45. Jurnal Akuntansi, 4(2), 165-174. http://majour.maranatha.edu/

Valintino, R., \& Sularto, L. (2013). PENGARUH RETURN ON ASSET (ROA), CURRENT RATIO (CR), RETURN ON EQUITY (ROE), DEBT TO EQUITY RATIO (DER), DAN EARNING PER SHARE (EPS) TERHADAP HARGA SAHAM PERUSAHAAN MANUFAKTUR SEKTOR INDUSTRI BARANG KONSUMSI DI BEI. Prosiding PESAT, 5 ,

8-9. http://ejournal.gunadarma.ac.id/index.php/pesat/article/viewFile/1187/1045

Widhiastuti, S., \& Nugraha, R. S. (2019). PENGARUH MODAL INTELEKTUAL, BIAYA PROMOSI, DAN PERPUTARAN PERSEDIAAN DALAM MEMPENGARUHI PROFIT SERTA IMPLIKASINYA TERHADAP NILAI PERUSAHAAN. Jurnal Manajemen Kewirausahaan, 15(2), 183-192.

Wljaya, I. B. N. P., \& Purnawati, N. K. (2014). Pengaruh Likuiditas dan Kepemilikan Institusional terhadap Nilai Perusahaan Dimoderasi oleh Kebijakan Dividen. E-Jurnal Manajemen Universitas Udayana, 3(12). 